\title{
Koolipärimuse kogumisest Noarootsis ja Vormsis 2006. aasta kevadel
}

\author{
Rootsi-Eesti lastenaljade kogumik Det var en ko och \\ det var poängen
}

\begin{abstract}
Teesid: Artiklis käsitlen Ahvenamaa Põhjamaade Instituudi (Nordens Institut på Åland) eestvedamisel korraldatud lastepärimuse projekti, mille käigus koguti 2006. aasta kevadel koolipärimust Soomest Ahvenamaalt ja Rootsist Gotlandilt ning Eestist endistelt rannarootsi aladelt. Kogutu põhjal ilmus sama aasta septembris rootsikeelne sissejuhatavate artiklitega antoloogiline naljakogumik Det var en ko och det var poüngen. Eesti aines on kogumikus esitatud paralleelselt eesti ja rootsi keeles. Keskendun välitööde kogumismetoodikale ja tulemustele Eestis. Välitööd toimusid aprilli- ja maikuus kahes Lääne-Eesti koolis: Noarootsi Koolis ja Vormsi Põhikoolis, pärimust koguti kümnel teemal, kirjalike küsitluskavale vastamiste kõrval kasutati suunatud intervjuud ja osalusvaatlust.
\end{abstract}

Märksõnad: Ahvenamaa, Gotland, koolipärimus, lastefolkloor, Noarootsi, Vormsi, välitööd

2006. aasta kevadel käivitus Ahvenamaa Põhjamaade Instituudi (Nordens Institut på Åland, http://www.nordinst.aland.fi/nordinst/) töötajate Lena Nymani ja Nina Smedsi eestvedamisel rahvusvaheline lastepärimuse projekt, mille eesmärk oli koguda Soomest Ahvenamaalt ja Rootsist Gotlandist ning Eesti endiste rannarootsi alade koolidest lastepärimust. Kolme Läänemere piirkonna lastefolkloorist koostati sissejuhatavate artiklitega antoloogiline naljaraamat Det var en ko och det var poüngen (Elas kord üks lehm ja ongi kogu lugu). Kogumiku pealkiri lähtub rootsi lastenaljast, mille eesti vaste on lakooniline anekdoodiparoodia: Elas kord üks käbi ja anekdoot sai läbi). 2006. aasta oktoobrikuus ilmunud kogumik on kakskeelne - rootsi lastelt kogutu (Ahvenamaa ja Gotlandi aines) rootsi keeles, eesti laste tekstid on lisaks tõlkele esitatud originaalkeeles - eesti keeles. Ahvenamaalaste projekt kordas 1988. aasta kogumistööd, mille põhjal ilmus samal aastal kogumik Blodet droppar, blodet droppar (Veri tilgub, veri tilgub; Bregenhøj \& Johnson 1988). 
Seitsmes Ahvenamaa koolis korraldas välitööd Nina Smeds, kes on ühtlasi väljaande koostaja ja toimetaja. Lastepärimuse kogumist Gotlandi neljas koolis kureerisid ning panid materjali raamatu jaoks kokku Gotlandi Kõrgkooli etnoloogiaprofessorid Ulf Palmenfelt ja Ove Ronström. Ulf Palmenfelt on ka kogumiku eessõna autor. Käesoleva artikli autori ülesanne oli Eestis kogumistöö korraldamine, kogutud ainese põhjal eesti osa koostamine ning eesti pärimusele analüütilise saatesõna kirjutamine. Eesti õpilaste lood tõlkis rootsi keelde Kadi-Riin Haasma, raamatu lustakad pildid joonistas kunstnik Jan-Peter Granlund.

\section{Eesti koolipärimuse kogumisest kuni käesoleva projektini}

Eesti, Ahvenamaa ja Gotlandi ühisprojekti kogumisretked ja jäädvustatud materjal paigutub eesti lastepärimuse kogumise üldisesse lukku. Eestis on lastepärimust sihipäraselt kogutud alates 20. sajandi teisest kümnendist. Aastatest 1921-1939 pärineb Walter Andersoni, ülemaailmselt tuntud rahvaluuleteadlase ning Tartu Ülikooli eesti ja võrdleva rahvaluule õppetooli esimese professori, lastelaulude kogu (58 832 lehekülge). Tema koostatud küsitluskava saatis rahvaluulearhiiv koolijuhatajatele, saades vastuseks laste kirjapanekud. Kooliõpilaste abi kasutas rahvaluulearhiiv korduvalt: aastatel 1931-1932 koguti sama metoodikaga materjali lastehirmutistest (16 köidet, 12000 lehekülge; vt ka Västrik 1997), aastatel 1934-1935 mängukirjeldusi (22 köidet, u 15000 kirjeldust) ja aastatel 1938-1939 kohapärimust (37 köidet, 16158 lk). Ka Matthias Johann Eisen kogus koolidest kalendritähtpäevade, perekonnatavandi, mängude jm kohta andmeid (1930.-1934. aasta, arhiivikogu E 64891-E 86457). Teise maailmasõja järelgi viidi läbi mitmed koolilastele orienteeritud küsitlused, mille juures kasutati nt lasteajakirja Pioneer abi (1958); koguti kohapärimust, lühivorme jm.

Rootsi folklooriainese kogumisega Noarootsis on enne Teist maailmasõda tegelnud põhjalikumalt Paul Ariste (M. J. Eiseni kogu E 60108-E 60469 ja kogu ERA, Rootsi 1), kes muu hulgas on Noarootsi murdes üles tähendanud ka lastetraditsiooni kuuluvaid folkloorivorme (nt sõrmenimetused, lastekeelsed kehaosade naljakad nimetused, liisklugemised, lastelaulud, lastehirmutised). Sellest materjalist on kasutatud rahvausundilist ainest (Kangur 2001), kuid lastepärimuse-alased uurimused praeguseni puuduvad.

Eesti folkloristidel on olemas ka rahvusvahelise koostöö kogemus koolipärimuse kogumisel. 1992. aasta suur kogumisaktsioon leidis aset Soome ja 
Eesti folkloristide ühisettevõtmisena. Soomest osales projektis 2200 õpilast, kellelt saadi 3996 lehekülge vastuseid. Üle-eestilise kogumisvõistluse käigus laekus Eesti Rahvaluule Arhiivi üle 27000 lehekülje rikkalikku ja väärtuslikku õpilasfolkloori ühtekokku 1797 vastajalt. Lääne-Eestist saadi toona kahetsusväärselt vähe materjali, Noarootsist ja Vormsist üldse mitte. Kogutud laste- ja koolipärimusest on avaldatud uurimusi (nt Lipitud-lapitud (Kõiva 1995); Contemporary Folklore (Kõiva 1996)) ja eesti laste hulgas populaarseid allikapublikatsioone (nt Kalmre 1995, 1999; Tuisk 1996; Voolaid 1998, 2003). Väiksema sihtrühmaga kogumisaktsioone toimus hiljemgi (eestivenelaste koolipärimus 1993., üliõpilaspärimus 1994. aastal, vahetunnifolkloori koguti interneti teel 1997. aastal jne).

Eesti folkloristidest on lastepärimust põhjalikumalt käsitlenud näiteks Anu Vissel (1952-2005) oma doktoritöös Lastepärimus muutuvas ühiskonnas (2004). Kui hea kolleeg poleks 2005. aasta septembris traagiliselt hukkunud, olnuks ta kõnealuse ühisprojekti Eesti-poolseks koordinaatoriks ning küllap ta kirjutanuks praegu minu asemel ka seda ülevaadet.

\section{Eesti välitööd ja kogumismetoodika}

Välitööd Eestis toimusid 2006. aasta aprilli- ja maikuus endisel eestirootslaste asualal kahes Lääne-Eesti koolis: Noarootsi Koolis ja Vormsi Põhikoolis. Koostööprojekti üks eesmärk oli tuvastada rootsi kultuuri mõju Eesti lääneranniku lastepärimuses.

Eesti Vabariigi ajal kultuuriautonoomiat omanud ja ligi 700 aastat Eestit asundanud minortiteedile tegi lõpu Teine maailmasõda. 1939. aastal rajas Venemaa oma sõjaväebaasid Lääne-Eestisse, mille tagajärjel hakati piirama ühiskonna traditsioonilisi tegevusalasid meresõitu ja kalapüüki. Rahva seas hakkasid levima emigratsioonimõtted ja aastatel 1943-1944 lahkus umbes 6800 eestirootslast Rootsi, kohale jäi 1281 inimest. Noarootsi ja Riguldi piirkonna tühjaksjäänud küladesse asusid elama sõjapõgenikud Ida-Eestist ja Ingerimaalt - katkes põlvest põlve pärandatud eestirootsi kultuur (vt nt Sarv 1994; Schönberg 2002). Praegu elab Noarootsi vallas umbes 900 inimest, neist ainult umbes 50 võib ennast pidada rootslaseks. Kogu Eestis elab umbkaudu 200-500 rootslast või nende järeltulijat.

Et Läänemaa mäletab oma minevikku, selle tõestuseks on seegi, et pärast Eesti Vabariigi taasiseseisvumist saavad Noarootsi Kooli lapsed lisaks tavapärastele kooliprogrammis ettenähtud ainetele alates esimesest klassist esimese võõrkeelena õppida rootsi keelt ning keskenduda põhjalikumalt ka 
Rootsi ajaloole ja kultuurile. Vormsi Põhikoolis õpitakse rootsi keelt alates 7. klassist. Tihedad sidemed Rootsi riigi ja rootslastega on olulised mõlemale koolile. Noarootsi Kooli külalisraamatust leiab sissekandeid paljudelt tuntud rootslastelt. Ükski teine põhikool Eestis ei saa uhkust tunda Rootsi kuninga Carl XVI Gustafi ja kuninganna Silvia visiidi üle, mis leidis aset 1992. aasta 24. aprillil.

138 õpilasega Noarootsi Kool asub Läänemaal Noarootsi poolsaarel Pürksis ning 21 õpilasega (õpilaste arv 2005/2006. õppeaastal) Vormsi Põhikool ligi 300 elanikuga Vormsi saarel. Kolmepäevase Noarootsi küsitluse tegin üksinda, pisut lühemal Vormsi ekspeditsioonil osalesid koos minuga kirjandusmuusemi fotograaf Alar Madisson ja rahvaluulearhiivi teadur Astrid Tuisk.

Välitöödel Noarootsis ja Vormsis kasutati ühesugust metoodikat. Saatsin koolidesse küsitluskava, millele lapsed õpetajate juhendamisel vastasid. Kaheleheküljeline küsitluskava koosnes kümnest teemast. Õpilastelt oodati: 1) anekdoote; 2) mõistatusi, naljaküsimusi ja -ülesandeid; 3) vanasõnu, argiarvamusi ja kõnekäände-paroole; 4) hirmu- ja absurdijutte; 5) paroodiaid, laule, salme; 6) mitmesuguseid ennustamisviise; 7) salmiku-, kaustiku- ja sõbraraamatute repertuaari; 8) harrastuste, kommete ja koeruste kirjeldusi; 9) mänge; 10) teavet interneti kasutamise kohta. Pärast kirjaliku materjali saabumist käisin õpilasi kohapeal intervjueerimas - Pürksis vestlesin 29, peamiselt 4.-6. klassi (10-12-aastased) õpilasega ja Vormsis nelja liitklassiga

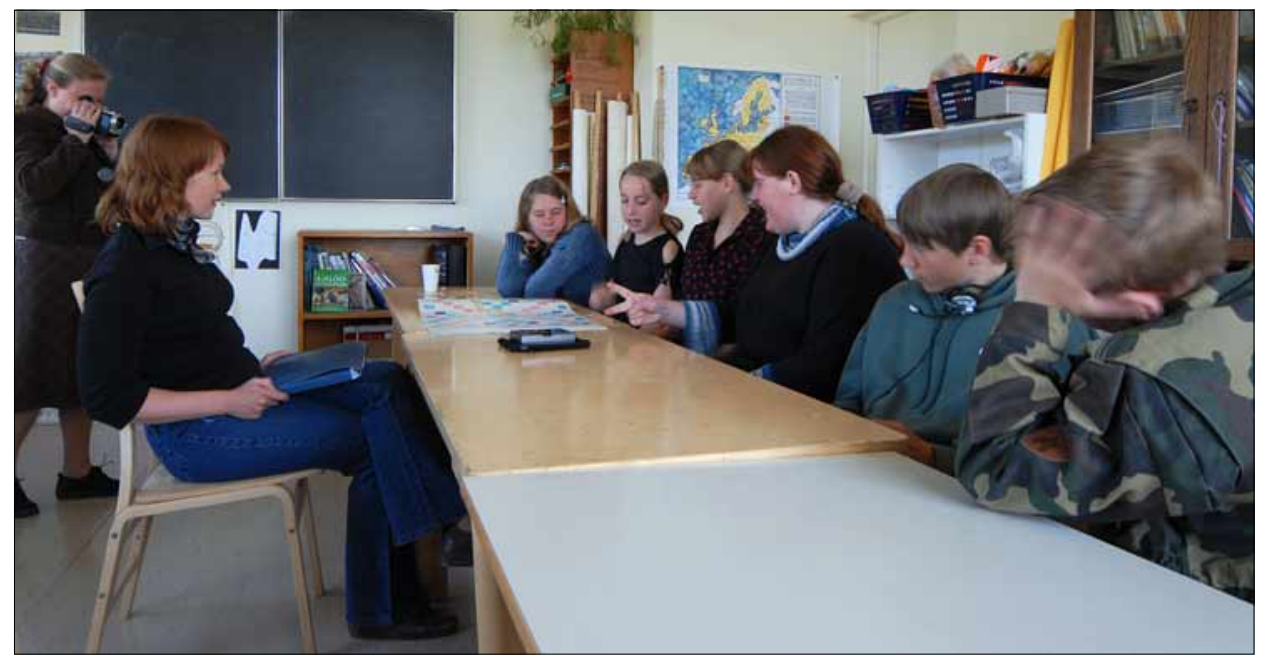

Foto 1. Piret Voolaid Vormsi kooliõpilasi intervjueerimas. Videokaamerat hoiab Astrid Tuisk. Alar Madissoni foto 2006. 
(8-15-aastased, ühtekokku 16 õpilast). Viisin emakeeletundide ajal klassiruumis läbi avatud rühmaintervjuud, mida ühtlasi lindistasin ja filmisin. Üldjuhul õpetajad küsitlemise juures ei viibinud, ent vestlus ühe rühmaga toimus ruumipuuduse tõttu direktori kabinetis direktori ja õppealajuhataja juuresolekul, mis võis mõjuda lastele kammitsevalt. Vormsis intervjueerisime ühe koolipäeva jooksul tundide ajal nelja rühma: 1.-2. liitklassi, 3.-4. liitklassi, 6.-7. liitklassi ja 8.-9. liitklassi. Küsimusi esitasin põhiliselt mina, Astrid Tuisk jäädvustas intervjuud videolindile, fotograaf Alar Madissoni ülesandeks oli olukorda kõrvalt pildistada. Intervjuud toimusid koolipäeva vältel, vabade tundide ajal tutvusime lisaks ka saare eluoluga.

Mõlemad külaskäigud erinesid mõnevõrra. Pürksis õnnestus mul ööbida kooli õpilaskodus, kus leidsin ennast juba esimesel õhtul otsesest pärimuskeskkonnast, sain õpilastega hea kontakti, kasutasin lisaks intervjueerimisele ka jälgimis- ja osalusvaatlusmeetodit. Kõik see võimaldas süveneda kogutava ainese konteksti ja vahetult tajuda kohalikku eluolu. Minu palvel demonstreerisid Noarootsi õpilased nii õpilaskodus kui ka koolivahetunni ajal mänge, ent mitmele vahetunni ajal aset leidnud mängule selle loomulikus esitussituatsioonis sattusin peale puhtjuhuslikult. Leidsin endale laste seast mitu sõpra, kellega olen MSN Messengeris hiljemgi suhelnud, et vajadusel lisainformatsiooni hankida.

Ekspeditsioonide tulemused - 90 lehekülge Noarootsi Kooli ja 15 lehekülge Vormsi Põhikooli vastuseid, ühtekokku üle 5 tunni helisalvestisi, 1,5 tundi videojäädvustusi ja 335 fotot - on korrastatud ja litereeritud kujul arhiivile üle antud.

\section{Pärimus Noarootsi ja Vormsi koolides 2006. aasta kevadel}

Kool on tänapäeva lapse teine kodu, tema peamisi suhtlemiskohti, kus kujuneb välja oluline eritasandiline sidemetevõrgustik. Omavahelises kommunikatsioonis on oluline osa elaval traditsioonil. Ühelt poolt suunavad laste traditsiooni täiskasvanud, teisalt on lapsed ise pidevalt looja rollis. Eesti õpetajad on eeskujuks kohalike traditsioonide arendamisel ja hoidmisel, olgu selleks siis rahva- ja koolikalendri tähtpäevade tähistamine või mitme põlvkonna suulise pärimuse kasutamine ainetundides. Noarootsi lastelt kuulsin, millise rikkaliku kombestikuga tähistavad nad erinevaid tähtpäevi, sealhulgas 13. detsembril ilmselgelt rootsi mõjutustega Lucia-päeva (eesti rahvakalendris tuntud kui luutsinapäev), ning kuidas nad kirjutavad emakeele 
tunnis ise muinasjutte. Vormsi laste sõnul mängitakse neil kehalise kasvatuse tunnis tihti põnevaid mänge, muusikatundides lauldakse rahvalaule jne. Kõik see näitab, et sageli on kool lapsele traditsiooniderikkamaid paiku, kus ühtlasi antakse edasi vanemat pärimust. Lapsel avaneb samal ajal võimalus luua ise midagi uut, kohandades arhailised, tuntud süžeed ümber vastavalt oma kasvukeskkonnale ja ajastule. Noarootsi ja Vormsi laste repertuaaris oli siiski väga palju ka varasemast ajast tuntud üle-eestilise levikuga folkloori.

Olen veendunud, et pelgad küsitluskava vastused oleksid jätnud kogumistöö puudulikuks. Esiteks nõuab küsitluskavale vastamine lastelt tükk aega ja võib muutuda ebameeldivaks kohustuslikuks ülesandeks, mis tuleb kaelast ära saada. Teiseks rõhutati küsitluskavas ja õpetajatele mõeldud juhendis, et vastata tuleb iseseisvalt ning vältida internetist või raamatutest mahakirjutamist - seda olnuks hiljem üsna keerukas kontrollida. Kolmandaks ei vasta teaduslik taksonoomia sellele, mida lapsed päriselus endale teadvustamata kasutavad ning muudab nende jaoks vastamise keerukaks jne. Anekdoot tundub kuulajatele kindlasti kõige naljakam loomulikus situatsioonis. Palve peale rääkida üks anekdoot võib laps päris vait jääda. Nii on näiteks ühiselamu õhtune magamaminekueelne pime ja põnev õhustik soodne kõiksuguste kummitus- ja õudusjuttude tekkeks ja esitamiseks, vastustes oli neid aga vaid paaril korral kirja pandud. Meeldiva üllatusena kohtasin eriti Noarootsis kindlate paikadega seotud suulist pärimust, valdavalt levinud süžeede ja motiividega usundilisi ja kohamuistendeid. Lapsed jutustasid mulle juba esimesel õhtul õhinaga, kuidas endisest lasteaiast ümber ehitatud õpilaskodu õuel asunud vanasti kalmistu, katku surnute matusepaik. Nüüd käivat sinna maetud inimesed õpilaskodus kummitamas. Sellest, kas seal surnuaed ka tegelikult asunud on, ei osanud õpetajad rääkida. ${ }^{1}$ Õpilaste ja õpetajate suust kuulsin põnevaid lugusid koolimajas (tegelikult ventilatsioonitorudes liikuva õhu mõjul) aset leidvatest salapärastest üleloomulikest juhtumitest, milles olevat peakangelaseks omaaegne legendaarne koolidirektor, õpetaja ja ühiskonnaelu tegelane Viktor-Valfrid Pöhl (1910-1986). Samuti on lokaalse folkloori ilming 1977. aasta 6. mail koolis puhkenud tulekahjuga seotud narratiivid, mille kohta tõene variant leidub kooli kroonikas (Belovas 2000: 42). Väga huvipakkuv on ka Pürksis asuva endise Lenini-nimelise kolhoosi sigala varemete kohta ringlev isiklikel kogemustel või teiste räägitul põhinev kummitusrepertuaar, mille järgi võivat vanast tondilossist möödujad kuulda surnud sigade ruigeid. Kui teise ekspeditsiooni käigus sigalat pildistamas käisime ja tohutusse varemetelasusse sisse astusime, võis vihiseva tuule ja kääksuvate uste ning sigade ruiete vahele tõepoolest paralleele tõmmata. Vormsi õpilased teadsid rääkida trolli-lugusid endisest nõukogude piirivalvekordonist, mida kohalikus kõnepruugis vene keele eeskujul sasta- 


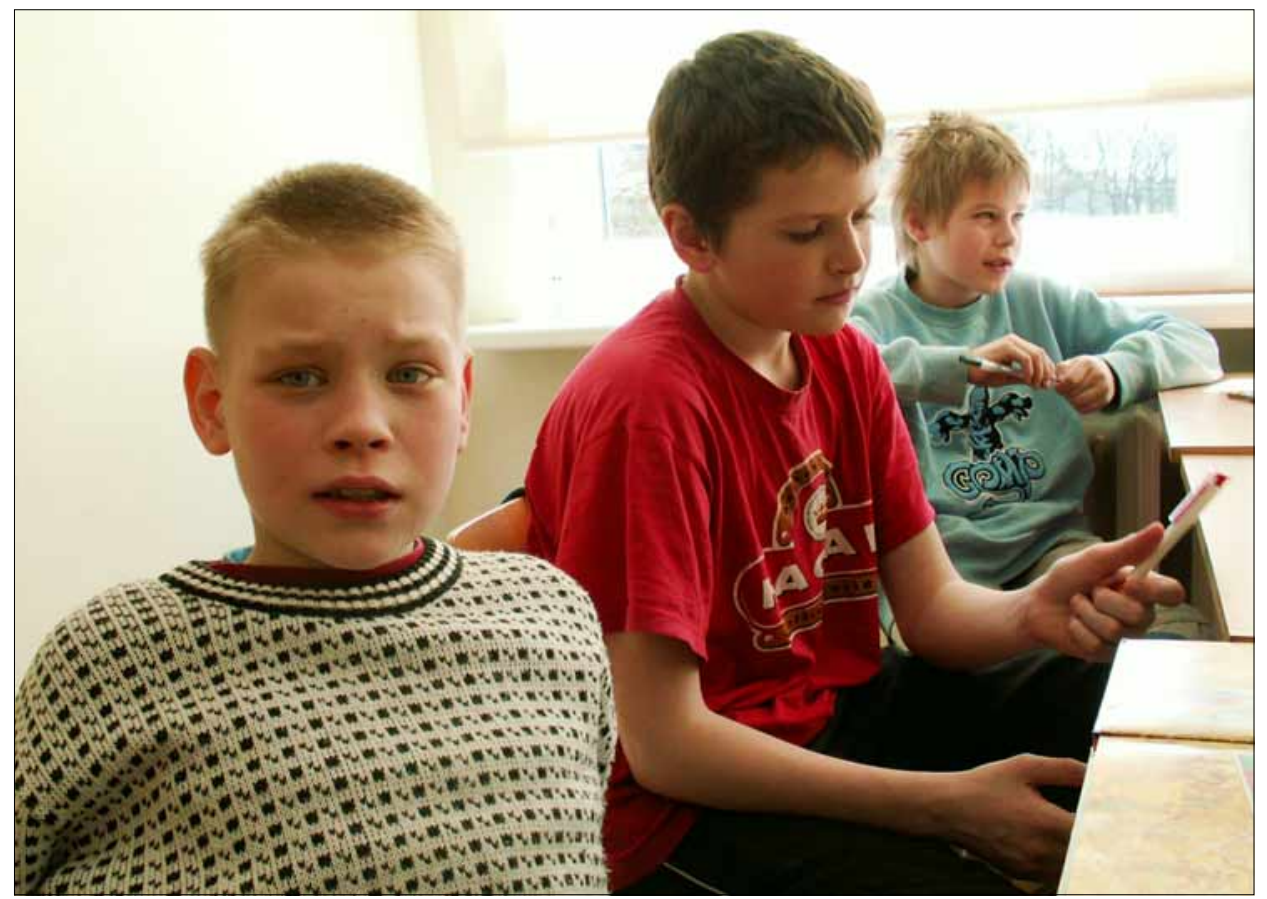

Foto 2. Noarootsi Kooli 4. klassi poisid jutte rääkimas. Esiplaanil hea anekdoodivestja Kristo Kuklase.

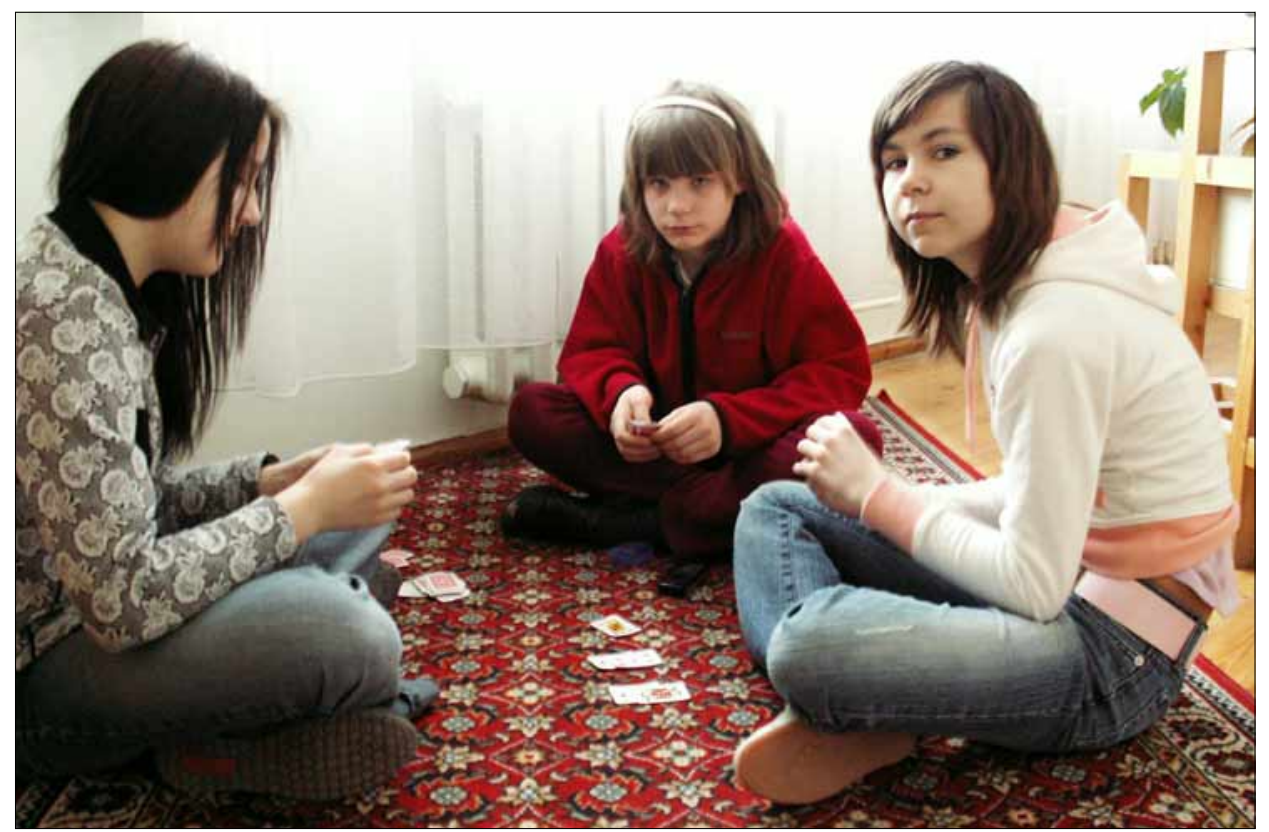

Foto 3. Noarootsi Kooli õpilasi võib vahetunnis kohata kaardimängu harrastamas. Piret Voolaiu fotod 2006 . 
vaks kutsutakse. Trollide puhul võib tegemist olla rootsi mõjutustega, sest eesti traditsioonis neist üldiselt teateid ei leidu. Õpilaste nn kummituspärimus ja tondijutud jäid küll seekord kogumikust välja, ent folklooriarhiivist on see hinnaline suuline pärimus uurijatele kättesaadav.

Žanriliselt leidus nii kirjalikes vastustes kui ka suulises esituses ootuspäraselt kõige enam anekdoote ja naljaküsimusi. Nagu Eesti koolilaste hulgas üldse, nii on ka Noarootsi ja Vormsi kooliõpilaste anekdoodirepertuaaris üheks populaarsemaks tegelaskujuks Juku - triksterlike omadustega ulakas koolipoiss, kellel laiskuse tõttu küll õppeedukusega probleeme, kuid kes igas elusituatsioonis (sageli ka seksuaalse alatooniga obstsöönsetes lugudes) leidlikult väljapääsu leiab ja sellega vaimuka puändi tekitab. Juku jõudis populaarse tegelasena eesti naljadesse ilmselt umbes 1960. aastatel. Seejuures viitab Juku-tsüklite suur sarnasus venelaste Vovotška-anekdootidega tõlkerepertuaarile. Analoogilised tegelased on ka näiteks kreeklaste Bobos ja soomlaste Pikku-Kalle.

Tänapäeva lastelt kogutud pärimuspalades on äratuntavad sekundaartraditsiooni ilmingud. Juku populaarsus seletub Eestis viimasel ajal hulgaliselt ilmunud Juku-teemaliste anekdoodikogumikega (nt Tungal 2001, 2004), mis on laste seas tohutult populaarsed. Sageduselt teisel kohal on rahvusvaheliselt tuntud süžeedega, osalt interneti vahendusel levivad blondiininaljad, mis eesti folkloori jõudsid 1990. aastate teisel poolel ja mis kätkevad sooliselt markeeritud stereotüüpe. Nii on blondiinist saanud ülima rumaluse võrdkuju. Laste anekdootides on populaarsed ka etnilised tegelaskujud, huumoriteooriatest tuntud juhmiskripti (Raskin 1985: 185-189) alusel loodud venelaenulised sotsiaalpoliitilise stereotüübiga tšuktšianekdoodid, aga ka rahvusvaheliselt tuntud süžeemotiividega kolme rahva naljad (üle-eestiliselt esindavad seda tüüpi anekdoote lood eestlasest, venelasest ja sakslasest), milles peatähelepanu on pööratud eestlase kui oma rahva esindaja esiletõstmisele. Kui 1992. aasta koolipärimuse kogumise aktsiooni käigus laekus arhiivi väga palju totalitaarset nõukogude režiimi pilavaid poliitilisi naljandeid ja poliitiliste anekdootide rääkimine võis olla omamoodi elustiil, siis sel ekspeditsioonil kogutu põhjal jäi mulje, et lasterepertuaarist on poliitiline temaatika kadunud. Suure osa omaaegsetest poliitiliste anekdootide rääkimise eesmärkidest täidab tänapäeval tsenseerimata meedia - võimuesindajate valeotsused ja väärteod ei vormu seetõttu suuliseks folklooripärimuseks.

Laste üheks meelepäraseks ühistegevuseks ja lahutamatuks kaaslaseks on mängimine. Arvutiajastul toimub suur osa meelelahutuslikust mänguelust küll virtuaalmaailmas ja internetis, ent sellegipoolest kirjeldasid õpilased 
mulle erinevaid reaalmaailma mänge. Üheks mängualustamise traditsiooniliseks võtteks, mille abil mängijatele rollid jaotatakse, on arhailistest uskumusmallidest välja kasvanud liisklugemise rituaal (Vissel 2004: 89), mille elujõuline järjepidevus avaldub äsjailmunud kogumiku eesti liisutussalmide hulgas (Smeds \& Palmenfeldt \& Voolaid 2006: 218-220). Kui 1929. aastal on Paul Ariste Noarootsi kihelkonnast Paslepa Algkooli 4. klassi õpilaselt üles kirjutanud liisusalmi

\author{
Entel, tentel trika trei, \\ oose, poose pokka trei, \\ en no kristjan pro, \\ siira viira to pis tut (ERA, Rootsi 1, 13 (1)),
}

siis aastal 2006 on samaealiste kooliõpilaste hulgas reaalse ja mängumaailma vahelise piiri ületamisel kõige populaarsem salm:

$\ddot{U} k i$-kaki, kommi-nommi, vanamees hüppas üle pommi.

Pommis käis üks kõva pauk, vanamees vaatas - püksis auk.

Püksist hüppas välja konn, küsis: "Kus su kodu on?"

"Minu kodu on kivi taga, sina oled mängust vaba!".

Traditsioonilised mõistatused on tänapäeva lapse repertuaaris oma koha loovutanud anekdoodi funktsiooni täitvatele otseküsimuse vormis naljaküsimustele, sõnamängudele ja piltmõistatustele, mille levikut mõjutavad tänapäeval ka arhiivimaterjali põhjal folkloristide poolt koostatud internetiandmebaasid (nt Eesti piltmõistatused - http://www.folklore.ee/Reebus). Vanasõnu ja ütlemisi teadsid lapsed nimetatud lühivormidest rohkem, kuid siingi ilmnes meedia mõju. Eriti huvipakkuv oli ühe Noarootsi Kooli 4. klassi poisi lausutud Haapsalu vanasõna: Valge väljas, vest seljas, pime väljas, piits peos. Tekst kuulub eesti vanasõnade akadeemilise väljaande järgi tüüpi 4259: Koit oues, kott kaelas; valge oues, vagu taga; pime oues, piits peus - 6 (42 varianti). Tõepoolest on tegemist lääne-eestilise levikuga vanasõnaga, mille versioon 4259D: Valge väljas, vart seljas; pime õues, piits peos on esindatud ühe Haapsalust üleskirjutatud variandiga. Küsimusele, kust poiss seda vanasõna kuulnud on, oli vastuseks, et leidis raamatust.

Tänapäeva pärimus seob ühte inimkultuuris püsivana säilinud elemendid ja ühiskonnas välja kujunenud tavad, mis on läbi teinud märkimisväärsed 
muutused. Uued kultuurinähtused (nt reisimine, sportimine, telerivaatamine, arvutisuhtlus) loovad pärimuse või selle uued vormid. Kuna lapsed ja noored on pärimusekandjatena vastuvõtlikumad, mõjutavad nende traditsiooni meedia ja massikultuur ka kõige rohkem. Noarootsi kooliõpilased parodeerivad klassiõhtutel populaarseid telesaateid, nagu "Miljonimäng" ja "Nõrgim lüli", jutustavad üksteisele ümber tõsieluseriaale ja filme, omavad kasutajakontot väga menukas tutvumis- ja suhtlusportaalis Rate (http://www.rate.ee). Varasem omatehtud salmikutraditsioon on asendunud poest ostetud tiražeeritud sõbraraamatutega, kus lapsel jääb üle vaid ankeet täita, kuid traditsioonilisi salmikesi, nagu näiteks

Roos närtsib, marmor puruneb,

kuid mälestus ei unune

või

Helen, Helen, väikene,

koolipoiste päikene.

Kõnnib ringi, näpp on suus,

südames on armastus!

kirjutatakse neissegi.

Nii kirjalikud vastused kui ka suulised intervjuud tõid arhiivi vähemal või rohkemal määral folklooriteateid kõigi küsitletud teemade kohta. Kogumiku koostamisprintsiibi järgi olid huvisfääris vaid lõbus lastehuumor, eesti repertuaarile plaanitud paarikümnele leheküljele (rootsi keeles lk 162-194, eesti keeles lk 196-225) mahtusid esijoones anekdoodid, naljaküsimused, liisklugemised, mõned pseudoõudusjutud, üks tuntud eesti lastelaulu Kes elab metsa sees? paroodia. Välja jäid kohapärimuslood, tähtpäevateated, mängukirjeldused, teave interneti kasutamise kohta, millele jääb arhiivi kaudu juurdepääs.

\section{Kokkuvõtteks}

Kogumiku Det var en ko och det var poängen tarvis kogutud aines ning raamatus sisalduv valimik on vaid fragment Noarootsi ja Vormsi laste elurõõmsast traditsioonist, üksnes põgus kokkupuude pärimusega, mis peegeldas nende laste maailma ühel kevadel. Vaimukat maailma, kus saavad kokku täiskasvanute elukogemused ja laste katsed omandada eluks vajalikke oskusi, vana ja uus, täiskasvanute küpsed teemad ja noorte siiras huvi täis- 


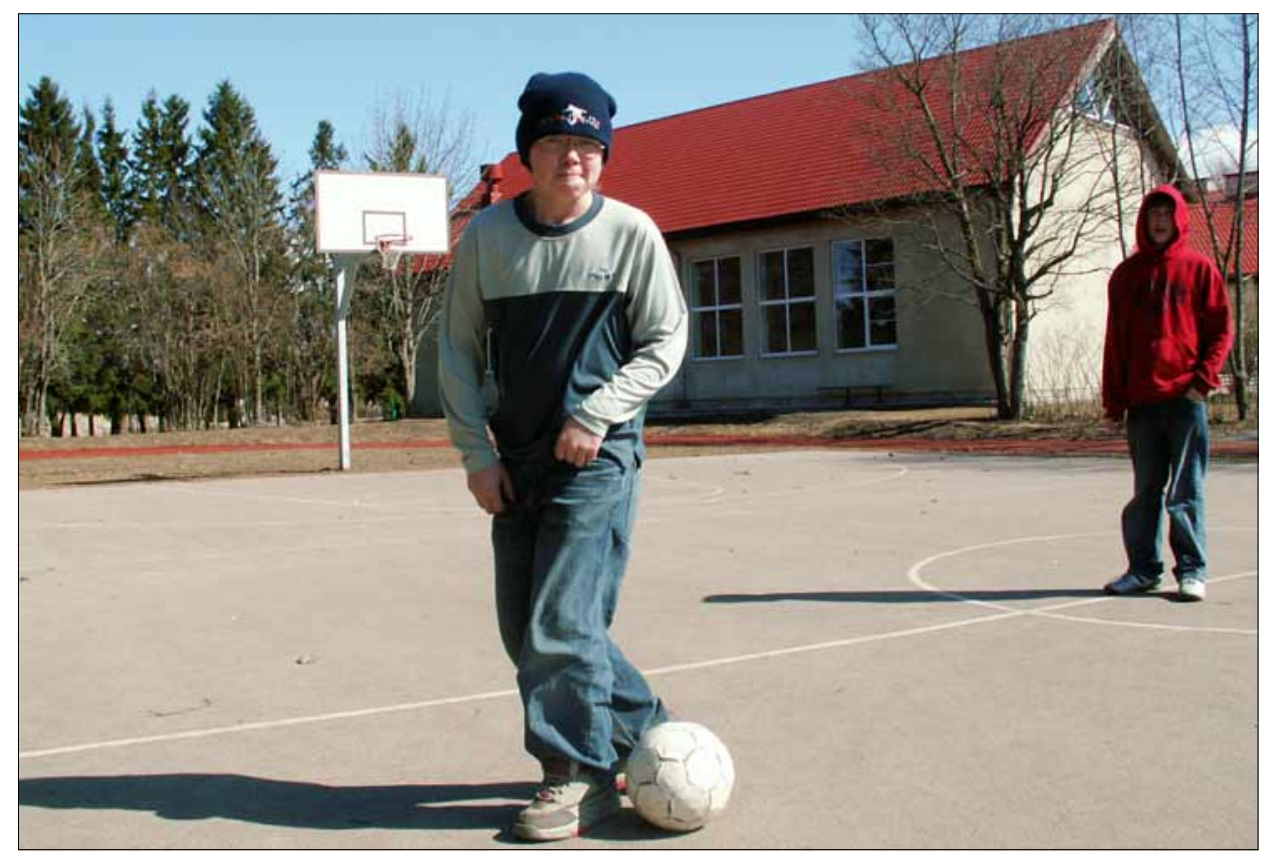

Foto 4. Pürksi koolipoiste lemmikmänge on vaieldamatult tribla. Tribla-asendit demonstreerib 6. klassi õpilane Jalmar Poks. Piret Voolaiu foto 2006.

kasvanute "keelatud" teemade vastu. Kokkuvõtvalt osutab välitöödel kogutud aines traditsioonidele ja innovatsioonidele, globaalsetele ja lokaalsetele ilmingutele ühe väikese piirkonna lastefolklooris. Tegemist on suures osas üleeestilise traditsiooniga, mis on levinud nii Vormsis ja Noarootsis kui ka mujal Eestis (Juku-anekdoodid, Rate’i pärimus, mängualustamisvõtted, mängud jne). Teisalt võib täheldada ülemaailmse pärimuse levikut ja sarnaseid jooni teiste rahvaste pärimusega (blondiininaljad jm). Valdavalt on vanem eesti lastepärimus (Juku-anekdoodid, tšuktšinaljad, teatud mängud) idapoolse päritoluga, järjest suureneb aga läänepoolse ning laiemalt üleilmse traditsiooni osakaal. Eesti on jätkuvalt omanäolise kinnistunud lastepärimusega ida ja lääne vaheline ala.

Lokaalseid jooni kohtab kogutud aines vähem. Lääne-eestilised on teatud mängude nimetused (läts, vt Vissel 1995: 269) ja Valge Daami väljakutsumine taldrikukeerutamisega ennustamisel (põhjus võib olla Haapsalu lähedus, kuid samas võib nähtus olla kultuurispetsiifiline, näiteks venelastel esineb väljakutsutavana pikovaja dama). Kohalikku koloriiti lisavad traditsioonilisele põhjale toetuvad laste endi loodud või ka vanematelt kuuldud kummi- 
tusjutud (Noarootsis nt sigala, kooli ja õpilaskoduga, Vormsis endise piirivalvekordoniga seotu). Paiga- ja traditsioonisidusus on suures osas katkenud, tuntud kohamuistendeid Pürksi mõisast ja mõisahärrast ning Noarootsi kirikust ei õnnestunud talletada (kuid sageli ei kuulugi selline kohapärimus nooremate laste repertuaari). Võrreldes varasema koolipärimusega on märgatav traditsiooni levikut hõlbustavate uute kanalite (internet, mobiilisuhtlus) esiletõus. Aktiivne pärimustraditsioon avaldub laste omavahelises suhtlemises, kus vanad tuttavad süžeed ja vormid teisenevad ja sulanduvad vastavalt keskkonna uutele nõudmistele.

Perspektiivne on eesti ainese võrdlus Ahvenamaal ja Gotlandil kogutud repertuaariga, mis avab paremini eri piirkondade ühisjooned. Loomulikult tasub võrrelda ja paralleele otsida ka 20. sajandi algusaegadel Noarootsist kogutud pärimusega, ehkki puutepunktide hulk on ilmselt väike ja võib eeldada samasugust pärimuse muutumistendentsi nagu muude piirkondade ja liikide puhul (nt etnilised anekdoodid, vt Laineste 2005), ent töö vääriks ettevõtmist.

Lõpetuseks tänan Ahvenamaa Põhjamaade Instituudi kolleege Nina Smedsi ja Lena Nymanit võimaluse eest projektis osaleda. Minu suurim tänu kuulub Noarootsi ja Vormsi kooliõpilastele, samuti õpetajatele Hella Koortile, Ly Kalmule, Tiina Järvele, Monika Undole ja Kaia Operile, kes sillutasid mulle teed Noarootsi ja Vormsi kooliõpilaste ja nende pärimuse juurde. Tegevust toetas ETF grant 6824.

\section{Kommentaar}

${ }^{1}$ Pürksist endise Nigårdsi talu maadelt on aastate jooksul mitmel korral leitud luid (Schmiedehelm 1924: 7; Lavi 1975: 1) ning koht on võetud muinsuskaitse alla (http://register.muinas.ee/pdetail01.asp?halu $=6 \&$ sele $=89 \&$ text $7=$ p\%FCrksi\&radiob2=0\&butt=Edasi\&mo_id=10064\&url=haldoman.asp) kui kalmistu. Arheoloogilise inspektsiooni aruandele tuginedes asub kalmistu põhiosa siiski lasteaiast kaugemal põhja pool, Pürksi-Hosby tee ääres. 


\section{Kirjandus}

Belovas, Laine (koost) 2000. Noarootsi kool läbi aegade: Noarootsi hariduselu 350. a. juubel. Noarootsi: Noarootsi Kool.

Bregenh ${ }_{s} \mathrm{j}$, Carsten \& Johnson, Maria (koost \& toim) 1988. Blodet droppar, blodet droppar!: Skolbarns humor. Glimtar ur Ålands folkkultur 4. Helsingfors: Schildt.

Kalmre, Eda 1995. Banaanil on nohu: Valik koolinalju ja muud. Tallinn: Koolibri.

Kalmre, Eda 1999. Roos närtsib, marmor puruneb...: Valik salme, nalju, mõtteteri ja ennustamisi tüdrukute albumitest. Tallinn: Koolibri.

Kangur, Kristi 2001. Noarootsi kihelkonna eestirootslaste usund. Bakalaureusetöö rootsi keele erialal. Käsikiri Tartu Ülikooli skandinavistika õppetoolis. Tartu: Tartu Ülikool.

Kultuurimälestiste riiklik register (http://register.muinas.ee - 19. detsember 2006).

Kõiva, Mare (toim) 1995. Lipitud-lapitud. Tänapäeva folkloorist 1. Tartu: Eesti Keele Instituut \& Eesti Kirjandusmuuseum.

Kõiva, Mare (toim) 1996. Changing World View and Tradition. Contemporary Folklore 1. Tartu: Institute of Estonian Language ja Estonian Museum of Literature.

Laineste, Liisi 2005. Tegelased eesti etnilises huumoris. Mäetagused: Hüperajakiri 28, lk 9-76 (http://www.folklore.ee/tagused/nr28/laineste.pdf - 10. detsember 2006).

Lavi, Ain 1975. Aruanne inspektsioonist Noarootsi ps. Pürksi külas. Käsikiri Tallinnas Ajaloo Instituudis, kasutuskoopia Tartu Ülikooli arheoloogia kabinetis.

Raskin, Victor 1985. Semantic Mechanisms of Humor. Synthese Language Library 24. Boston: Dordrecht Reidel.

Sarv, Ain (koost) 1994. Varjusurmast tõusnud: Eestirootslaste ja eestirootsi alade saatusest pärast Teist maailmasõda = Fran skuggornas värld - ater till livet. Tallinn: Huma.

Schmiedehelm, Marta 1924. Noarootsi khl. arheoloogiline kirjeldus. Käsikiri Tallinnas Ajaloo Instituudis, kasutuskoopia Tartu Ülikooli arheoloogia kabinetis.

Schönberg, Alar 2002. Estlands svenskar. Ohlsson, Stig Örjan \& Tuldava, Juhan (toim). De skandinaviska länderna och Estland = Skandinaaviamaad ja Eesti = The Scandinavian countries and Estonia : proceedings of the International Conference dedicated to Prof. Stig Örjan Ohlsson on his 60th birthday in December 1999 at the University of Tartu, Estonia. Nordistica Tartuensia 5. Tallinn: Pangloss, lk 57-60.

Smeds, Nina (toim) \& Palmenfeldt, Ulf (sissejuhatus) \& Voolaid, Piret (analüüs) 2006. Det var en ko och det var poüngen. [Mariehamn]: Nordens Institut på Åland.

Tuisk, Astrid 1996. Neeger päevitab: Maailma rahvad Eesti laste naljades. Tallinn: Koolibri.

Tungal, Leelo ２001. Jälle see Juku!:Anekdoodid. Tallinn: Ilo. 
Tungal, Leelo 2004. Juku ja teised: 555 anekdooti. Lapsuri raamatukogu. Tallinn: Hea Laps.

Vissel, Anu 1995. Traditsiooniline ja uuenduslik Eesti tänapäeva lastemängudes. Kõiva, Mare (toim) 1995. Lipitud-lapitud. Tänapäeva folkloorist 1. Tartu: Eesti Keele Instituut \& Eesti Kirjandusmuuseum, lk 255-324.

Vissel, Anu 2004. Lastepärimus muutuvas ühiskonnas. Ars musicae popularis 15. Tartu: Eesti Kirjandusmuuseum, etnomusikoloogia osakond (http://www.utlib.ee/ekollekt/ diss/dok/2004/b16859947/vissel.pdf - 19. detsember 2006).

Voolaid, Piret 1998. Elevant külmkapis: Kimbuke keerdküsimusi eesti koolilaste suust. Tallinn: Koolibri.

Voolaid, Piret 2003. Kaelkirjak akna taga: Põimik piltmõistatusi. Tallinn: Koolibri.

Västrik, Ergo 1997. Eesti lastehirmutised ja C. W. von Sydowi fiktsiooniteooria. Bakalaureusetöö. Käsikiri Tartu Ülikooli eesti ja võrdleva rahvaluule õppetoolis. Tartu: Tartu Ülikool.

\section{Summary}

\section{On Collecting School Lore in Noarootsi and on Vormsi Island in Spring 2006}

\section{Anthology of Swedish and Estonian Children's Jokes Det var en ko och det var poängen}

Piret Voolaid

Key words: Åland, Gotland, school lore, children's lore, Noarootsi, Vormsi, fieldwork

The article reviews the project of collecting school lore, instigated by Nordens Institut på Åland (the Nordic Institute on Åland) which aim was to collect school lore from Åland (Finland), Gotland (Sweden) and the former regions of coastal Swedes in Estonia in spring 2006. The collected material was published in a Swedish-language joke anthology Det var en ko och det var poängen ('Once there was a cow - and that's it!'), in which the Estonian material is presented in two languages.

In Estonia, the fieldwork for the project was carried out in April and May, 2006, in two general education schools in West Estonia: in Noarootsi School (with 138 pupils) and Vormsi Basic School (21 pupils).

I undertook the three-day field trip to Noarootsi on my own, whereas on the twoday trip to the Vormsi Island I was accompanied by Alar Madisson, photographer of the Estonian Literary Museum, and Astrid Tuisk at the Estonian Folklore Archives. The choice of these two rural schools for folkloric fieldwork was made by our Swedish partners, who argued that these remain in the former settlement areas of the coastal 
Swedes and were particularly interested in the contemporary school lore of this particular region, which has been inhabited by Estonian Swedes for nearly eight centuries.

The same fieldwork methods were applied in Noarootsi and Vormsi. First, the schoolchildren responded to questionnaires under the supervision of teachers. The questionnaires were based on one used in the 1992 major collection campaign for collecting school lore in Estonia. The children were asked to write down 1) jokes; 2) riddles, conundrums and trick tasks; 3) proverbs, truisms and set phrases/quip words; 4) horror tales and absurd tales; 5) parodies, songs, verses; 6) various predictions; 7) the repertoire of verse books, notebooks and friendship books; 8) various hobbies, customs and tricks; 9) games; 10) information on using the Internet. This was followed by in situ interviewing of children: 29 children from grades 4-6 (ages 10-12) were interviewed in Pürksi and children from four mixed year classes in Vormsi (ages 815 , the total of 16 pupils). In addition to directed interviews, participation observation was used.

The fieldwork expedition resulted in 90 pages of archive material, consisting of questionnaire responses from the Noarootsi School and 15 pages of responses from the Vormsi Basic School, constituting over 5 hours of audio-recordings, 1.5 hours of video-recorded material and 335 photographs.

The selection of material published in the anthology is only a small part of the lively tradition of the children of Noarootsi and Vormsi: the material reflects only a moment in the folkloric process with a focus of specific children. The material collected at fieldwork refers to traditions and innovations, the global and regional phenomena in the children's lore of a small area. All traditional folklore genres were represented: the responses to the questionnaires as well as oral interviews included mostly jokes and conundrums, minor forms, games, as was expected, and quite surprisingly also religious and local legends.

The material largely reflects the all-Estonian tradition, which is known on Vormsi Island, in Noarootsi, and elsewhere in Estonia (jokes about Juku, lore connected with dating portal www.rate.ee, counting-out rhymes, games, etc.). However, the region's lore also reflects the global migration and characteristic features can be found with the lore of other countries (blonde jokes, etc.). The older Estonian children's lore (jokes about Juku, Chukchi jokes, certain games) is largely of eastern origin, although the proportion of western and international tradition is increasingly growing. Estonia continues to be the area with a highly unique fixed children's lore between the east and the west.

The collected material displays less regional characteristics. The peculiarities of West-Estonian lore are manifest in the names of certain games, and summoning the White Lady with an Ouija board (this may be explained by the close location of the town of Haapsalu, in the castle window of which the figure of the White Lady is seen, but the phenomenon may also be culture-specific - e.g. the Russians summon pikovaia dama, or the Queen of Spades). The local colouring is added by ghost or horror tales, which are created by the children or which they have heard from their parents, but which are based on a traditional plot (e.g. in Noarootsi, the tales are about the pig farm, the school building and the dormitory, in Vormsi about the former local border guard station). Compared to the earlier school lore, the contemporary tradition is 
being increasingly spread through new channels (WWW, mobile phone communication).

The active lore tradition is also expressed in the communication between children, in which old plots and forms are altered and adapt to new environments. 